\title{
A REVIEW AND CRITIQUE OF COMMANDER THEORY
}

\author{
Dr. Il-woon Kim \\ Professor of Accounting and International Business \\ George W. Daverio School of Accountancy \\ University of Akron, USA \\ E-mail: ikim1@uakron.edu \\ Dr. Phillip C. James \\ Assistant Professor of Accounting \\ School of Business and Liberal Arts \\ State University of New York, Canton, USA \\ E-mail: jamesp@canton.edu
}

\begin{abstract}
The development of accounting was marked by three key theories namely: the proprietary theory, the entity theory and the fund theory. The commander theory was subsequently introduced to address the criticisms of the previous theories. This paper, therefore, outlines the history and development of the commander theory, it also outlines the essence of the theory and discusses general criticisms levied against it. Despite some apparent weaknesses of the commander theory, one of which is that it is in-ward focused, thereby ignoring those outside the firm, it is simultaneously argued that the commander theory should be viewed as a significant theoretical framework in the formulation of accounting standards.
\end{abstract}

Keywords: Commander Theory, Critique.

JEL Classification Codes: M41.

\section{INTRODUCTION}

Accounting procedures are perceived from a particular individuals' or groups' point of view. Consequently, accounting objectives, standards, and techniques are different, depending on these viewpoints. Three theories or propositions were developed during the evolution of accounting. They are the proprietary theory, the entity theory, and the fund theory. A fourth theory-the commander theory - was introduced in 1965. Even though none of them have complete support, the first three theories are well known and some of their characteristics are reflected in modern financial accounting concepts and procedures. The commander theory, developed by Goldberg (1965) as a result of criticisms on the proprietary, entity, and fund theories, is not well accepted or known among accountants due to its stewardship nature.

In spite of the lack of understanding of the commander theory, modern finance theories and recent evidence due to the study of capital markets provide justification for reconsidering the value of the theory. This paper explains the history and background for development of the commander theory, introduces the essence of the theory, and discusses criticisms and its potential contributions from the perspective of modern financial accounting. It is argued that the commander theory, although it may have been forgotten, should be seriously considered as a viable criterion in the formulation of accounting standards and techniques.

\section{THREE THEORIES OF ACCOUNTING}

In this part, three theories that had been developed prior to 1965 are discussed briefly. They are the Proprietary, Entity, and Fund theories. 


\section{Proprietary Theory}

Pacioli's transaction analysis had focused on proprietorship (Chatfield, 1977). The proprietary theory was presented in complete form by Sprague (1908) in his famous book, The Philosophy of Accounts, published in 1908. Since that time, the theory of accounting has been saturated with the proprietorship concept. Consequently, in the usual treatment of the subject, the structure of accounts is described from the point of view of the proprietor (Paton, 1922).

The primary objective of the proprietary theory is the determination of the proprietor's net worth, available for withdrawals without impairing capital. The proprietor is the center of accounting interest, and a clear distinction is made between liabilities and equities. The accounting equation described by Sprague (1908) is: Assets - Liabilities $=$ Proprietorship.

The theory is balance sheet oriented in the sense that assets are valued in order to measure the change in the proprietor's interests by the changes in balance sheet amounts.

Assets represent benefits owned by the proprietor or benefits accruing to him. Liabilities are owner's debts. Capital shows the firm's value to its owner. Revenue immediately increases proprietorship; expenses decrease it. Net profit accrues directly as wealth to the owner. All types of income can be treated very much alike, since all go to owner's equity and similarly affect it. For the same reason, little distinction need be made between losses and expenses (Chatfield, 1977).

\section{Entity Theory}

Paton's (1922) critique of proprietary accounting was that it was not an entirely adequate accounting system under the conditions of a modern business organization. He argued that the techniques of accounting had developed rapidly to meet corporate needs, but theory still assumed that disclosure of proprietor's capital was the main accounting task. If the corporation is functionally separate from its owners and creditors, then it should be the center of accounting interest. He then presented a new accounting model: Assets = Equities. Equities represent sources of the assets and consist of liabilities and stockholders' equities.

While the proprietary theory is mainly concerned with the balance sheet and legal concept of capital, the entity theory emphasizes corporate income to meet the claims of the equity holders and is, consequently, income statement oriented. Revenues are compensation for services provided by the firm. Expenses measure the cost of services consumed in obtaining the revenue. Profits accrue to the corporation, not to its owners or creditors. The sources of financing are not important to the corporation and all returns of capital to suppliers are distributions of profits, not expenses.

\section{Fund Theory}

Vatter (1947) rejects both proprietary and entity theories because they adopt a personality as their focus of attention. The only difference between the two theories is that the person is a human being (proprietary) in the proprietary theory and an abstract being (entity) in the entity theory. The major problem of the personalized base for accounting is that the contents of accounting reports will tend to be affected by personal analogies. The demand for accounting information by investors, management, and government are too varied to be served adequately by adopting any single personality. In place of such personalities, Vatter advocates the use of the fund as the basic concept by which accounting thought and practice should be developed.

Vatter defines a fund as a collection of service potentials (e.g., assets) that have been brought together for some functional purpose: administrative, entrepreneurial or social. A fund is an entity established to isolate and control particular activities of administration.

The basis of accounting is a group of assets and related obligations and restrictions governing the use of the assets called a "fund." Thus, the theory views the business unit as consisting of economic resources (funds) and related obligations and restrictions in the use of these resources. The accounting equation is viewed as: Assets Restrictions of Assets. The accounting unit is defined in terms of assets and the uses to which these assets are committed. The statement of sources and uses of funds, which reflects the operations of the firm in terms of sources, is most important (Belkaoui, 1981).

The fund theory is useful to government and non-profit organizations. As Vatter admits, however, the theory fails to measure profit accurately. 


\section{GOLDBERG'S CRITICISM}

As discussed above, the proprietary theory looks at accounting from the viewpoint of shareholders and the entity theory from that of the business. Goldberg (1965) rejects both theories on the grounds that the point of view of the manager is completely ignored and emphasis is placed on ownership rights. He argues that since the day-today control of property is vested in the manager, attempts should be made to account for such control of property in addition to its ownership. He points out that ownership is a nebulous and difficult to define concept.

His criticism of the fund theory is somewhat more severe. He argues that there are both conceptual and practical difficulties in defining the fund and in applying the theory. First, the fund is defined in terms of assets and equities, and it is just as much an abstraction as the entity. Different accountants have different views on what constitutes funds in the activities of a business. It cannot then be said that the theory is, as Vatter asserts, devoid of personal implications. Fund theory, therefore, provides help just comparable to that of the entity theory in explaining accounting procedures. Second, fund theory is not an explanatory theory at all. The argument is simply this: if we adopt the fund as the fundamental concept in accounting, then the logical outcome is a set of reports very different from those which have been in use in accounting for many years. It does nothing to explain the present reports, but is purely advocative of a very material change in procedures.

\section{COMMANDER THEORY}

Based on the criticisms on the proprietary, entity, and fund theories, Goldberg (1965) proposed a new "commander" theory in which accounting procedures were carried out from the point of view of the commander rather than that of the owner or artificial entity. However, he was actually not the first who advocated this functional view of accounting. For example, Paton (1922) noted: "If the most important purpose which modern accounting can serve lies in the rationalizing of business administration, the accountant must of necessity adopt the viewpoint of the manager in large measure". Scott (1925) advanced a similar argument: "Since accounting is essentially a tool of management the point of view of accounts must be that of the managers. The scope of the accounting system must be co-existent with the authority of the management". In the following sections, the essence of, and support for, the commander theory is discussed.

\section{Explaining the Theory}

In a sole proprietorship, the owner has command over resources and makes a choice between alternative uses of those resources. Therefore, there is no distinction between the owner and commander. In a corporation, however, the investors have command over their resources until they become shareholders. At the moment when they purchase the stock, they transfer their command over the resources to the manager. Hence, they have ownership interests in the resources of the firm but have no direct control over them. In other words, the diffusion of ownership prevents the stockholders from controlling company policy, and they are seldom the driving force in modern corporations. Investors retain command only over the resources distributed to them as dividends.

The most strategic view of corporate activities is that of the commander who makes the decisions and guides the business from day-to-day. The command over the company's resources is exercised by a hierarchy of commanders. Accounting emphasis, therefore, should be on how effectively the management has used corporate resources. Accounting data should also provide useful information for commanders making economic decisions. In this context, the balance sheet is a statement of accountability for the resources placed in management's care. The income statement measures the results of managerial activities and shows how resources have been used to achieve these results. The fund statement expresses how managers have obtained resources and what they have done with them. In a few words, the commander theory makes financial statements on stewardship.

It should be noted that the term "commander" is used rather than "manager" to signify the person that has command over the resources. Goldberg believes that this notion enables accountants to arrive at a realistic interpretation of the purposes and functions of accounting without recourse to artificial abstractions such as an entity or fund.

Based on Goldberg's agreements, the following two propositions can be summarized:

Proposition 1: The accounting data should provide useful information to the commander to make optimal economic decisions. 
Proposition 2: The accounting data should provide useful information to investors to evaluate how effectively the commander has used corporate resources.

\section{Support for the Theory}

In this section, Fisher's theory of investment decisions, which is well explained in Hirshleifer (1965), will be introduced to defend proposition 1 . Some evidence on capital market studies will then be used along with Fisher's theory to defend proposition 2.

In Fisher's economic framework, the objects of choice are present consumption $\left(\mathrm{C}_{0}\right)$ at time 0 and future consumption $\left(\mathrm{C}_{1}\right)$ at time 1 . Each individual is assumed to attempt to maximize utility within their opportunity sets. There exist three different categories within the opportunity set: endowment (Y), financial opportunities, and productive opportunities.

In Figure 1, without financial or productive opportunities, an individual with an initial endowment at time 0 and time 1 ( $\mathrm{Y}_{0}$ and $\mathrm{Y}_{1}$, respectively) will consume the endowment and get utility $\mathrm{U}_{1}$. If financial markets exist, then the individual can reach any point along the market line $\left(\mathrm{M}^{\prime} \mathrm{M}\right)$ by borrowing or lending at the market interest rate. The individual's utility will be increased from $U_{1}$ to $U_{2}$ by moving from point $A$ to point $B$ through lending.

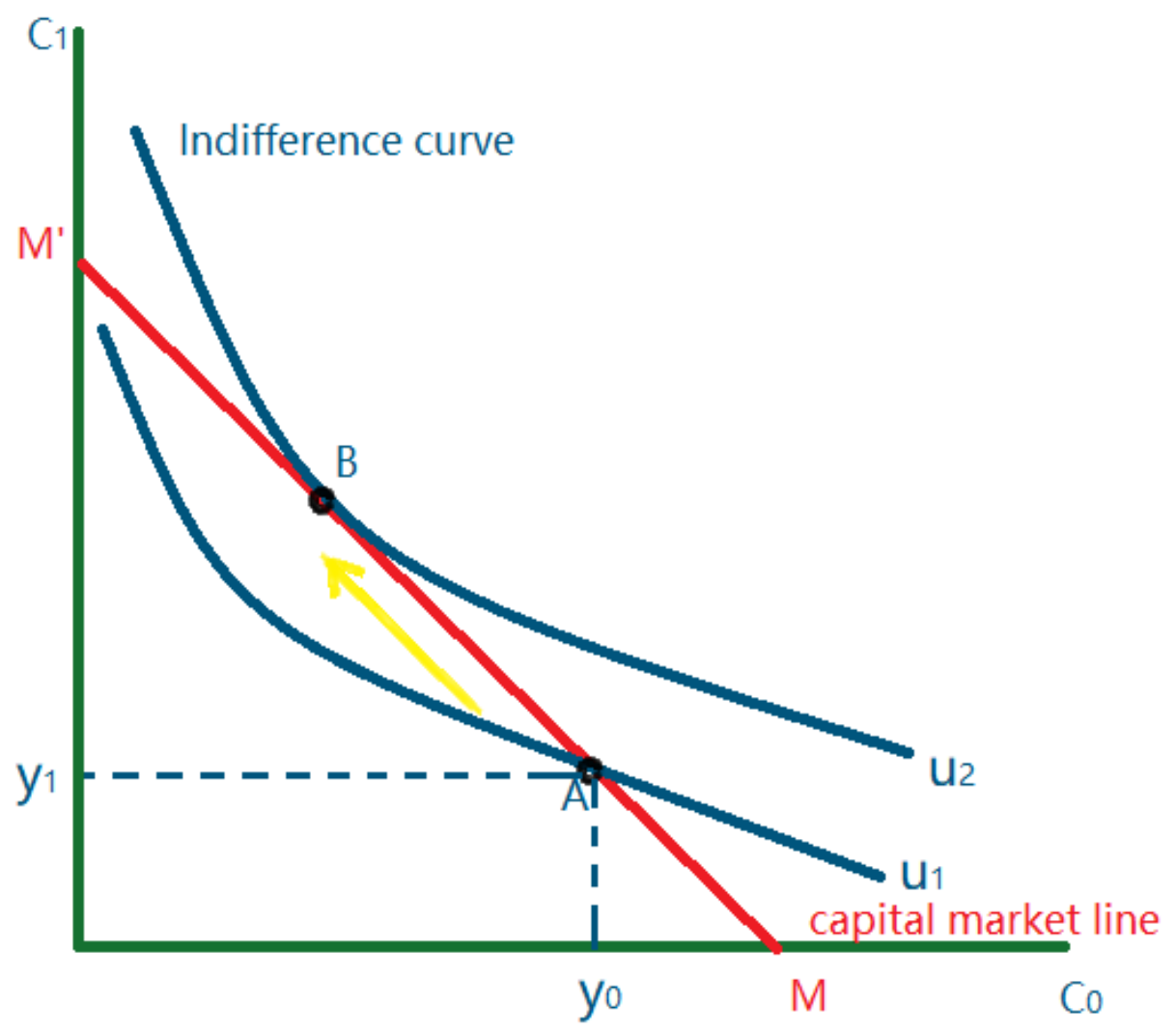

Figure 1. Indifference curve relationship with capital market line 


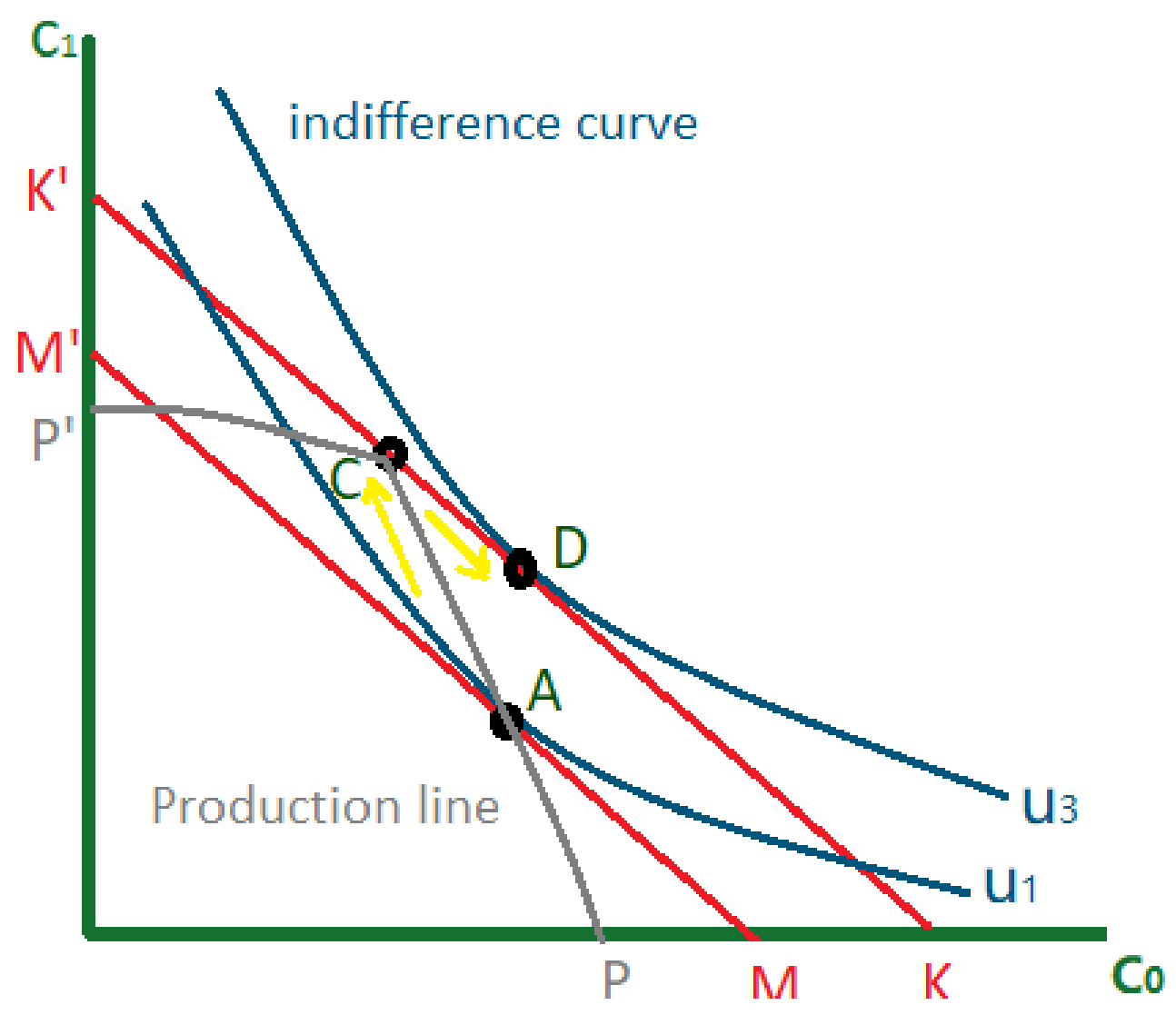

Figure 2. Indifference curve relationship with production line

With production opportunities ( $p^{\prime} \mathrm{p}$ ) in Figure 2, however, the individual can do better. Starting at the initial endowment $A$, the individual can move either along the capital market line (M'M) or the production line $(\mathrm{P} ' \mathrm{P})$. Both alternatives offer a higher rate of return, but the individual will move along the production opportunity frontier up to $\mathrm{C}$ since production offers the highest return. At point $\mathrm{C}$, the marginal return on investment is equal to the market interest rate, and the individual can reach any point on a new capital market line $\left(\mathrm{K}^{\prime} \mathrm{K}\right)$. The individual will then be better off by moving to point $\mathrm{D}$ by borrowing, where the maximum level of utility U3 is obtained.

The result of this theory is the separation of the investment and consumption decisions (Fisher separation theorem). Given perfect and complete capital markets, the production decision is governed solely by an objective market criterion without regard to the individual's subjective preferences.

The implication of this theorem is important to accountants. The theorem says that, given the same opportunity set, every investor will make the same production decisions (D in Figure 2), regardless of the preferences of their consumption patterns. Consequently, in theory, production decisions can be delegated to the manager. The delegation process places the manager at the center of the business, and, therefore, accounting information systems should be designed in such a way as to provide useful information to the manager in order to make optimal production decisions. This result is consistent with proposition 1.

It might then be argued that management accounting could serve this purpose. In the following paragraphs, however, it is argued that financial reports should disclose traditional management accounting information for investment decisions by investors.

There exist two serious problems in delegating decision-making authority to the manager. First, due to the reality of widespread ownership of a modern corporation, owners no longer have effective control over managers. On paper at least, shareholders elect the board of directors, and it is they who appoint management. It, therefore, seems that shareholders have absolute power over management. This is, unfortunately, not the way it works in practice, especially for large corporations. Managers generally have considerable discretionary power 
to pursue whatever objectives they wish. Second, there is evidence that capital markets are not efficient in the strong form. For example, Jaffee (1974) and Lorie and Neiderhoffer (1968) found that corporate insiders earned returns in excess of expected returns. The result indicates that managers have monopolistic access to information about their firm. This private information is not available to the investors.

It is, therefore, fairly possible that managers take advantage of investors' inability to control and exploit inside information to make abnormal profits. This result is unsatisfactory because of the illegality of using inside information for trading in a firm's stock, and it would also result in an inefficient capital market and subsequent suboptimal allocation of scarce resources. To resolve these problems (at least partially), investors should be provided with any information that is useful in scrutinizing managers, so that they do not misuse inside information and, therefore, attempt to reach the optimal production point ( $\mathrm{D}$ in Figure 2). This result is consistent with proposition 2 .

\section{SUMMARY AND CONCLUSIONS}

It has been argued that production and investment decisions can be delegated to the manager in theoretical sense. This theory especially holds true for large corporations. Consequently, a major function of accounting has been to provide any information to managers in order to make optimal economic decisions. It has also been argued that it is possible for managers to pursue their own objectives using monopolistic power and inside information. Investors, therefore, should be provided with accounting information by which managerial decisions can be evaluated. All of these arguments are consistent with the commander theory.

It should be recognized, however, that the commander theory also possesses weaknesses. Chatfield (1977) argues that managers direct company operations but the corporation must also interact with its environments. Therefore, accounting theories should consider the external political and social influences on decision making as well as the recipients of accounting information. Since the commander theory ignores groups outside the firm and focuses entirely on decision makers within the firm, he criticizes the theory in that it does not offer a comprehensive description of business activities, nor a basis for evaluating the whole spectrum of accounting concepts and methods.

It appears that none of the theories are complete, but each one has its own merits. They are also not mutually exclusive. The influence of the proprietary, entity, and fund theories can be found in many of the accounting standards and techniques currently used. For example, the net income arrived at after treating interest and income taxes as expenses connotes a proprietary emphasis. The corporate form of business is viewed as a separate and distinct unit from its owners, according to the entity theory. The fund theory is useful to government and non-profit organizations. The commander theory, however, has not received much attention by accountants. In this paper, it has been shown that it is serious in the process of formulating accounting standards and techniques.

\section{REFERENCES}

Belkaoui, A. (1981). Accounting Theory (New York; Harcourt Brace Jovanovich, Inc., 1981).

Chatfield, M. (1977). A History of Accounting Thought (Huntingdon, MA: RE Krieger).

Goldberg, L. (1965). An Inquiry into the Nature of Accounting-American Accounting Association Monograph No. 7. Menasha, WI: George Banta Company.

Hirshleifer, J. (1965). Investment Decision under Uncertainty: choice-theoretic approaches. The Quarterly Journal of Economics, 79(4), 509-536.

Jaffe, J. F. (1974). Special information and insider trading. The Journal of Business, 47(3), 410-428.

Lorie, J. H., \& Niederhoffer, V. (1968). Predictive and statistical properties of insider trading. The Journal of Law and Economics, 11(1), 35-53. 
Paton, W. A. (1922). Accounting theory: with special reference to the corporate enterprise. Ronald Press Company.

Scott, D. R. (1925). Theory of Accounts.. (Vol. 1). H. Holt.

Sprague, C. E. (1908). The Philosophy of Accounts. New York: The Ronald Press Company.

Vatter, W. J. (1947). The Fund Theory of Accounting and Its Implications for Financial Reports (Chicago; The University of ChicagoPress, 1947), pp. 1-13. Reprinted in Contemporary Studies in the Evolution of Accounting Thought, edited by M. Chatfield (Belmont, California; Dickenson Publishing Co., 1968), pp. 95-112.

\section{Copyrights}

Copyright for this article is retained by the author(s), with first publication rights granted to the journal. This is an open-access article distributed under the terms and conditions of the Creative Commons Attribution license (http://creativecommons.org/licenses/by/4.0/) 